Pak. j. sci. ind. res. Ser. B: biol. sci. 2020 63A(1) 37-47

\title{
Development and Quality Evaluation of Ready to Serve Olive and Mandarin Blended Diet Drink
}

\author{
Atta Ur Rehman ${ }^{a}$ Ihsan Mahbood Qazi ${ }^{a}$, Arsalan Khan ${ }^{b *}$, Falak Naz Shah ${ }^{b}$, \\ Abid Shah Shinwarib, Qamar Zeb ${ }^{b}$ and Muhammad Kaleem ${ }^{\mathrm{a}}$ \\ ${ }^{a}$ The University of Agriculture Peshawar, KPK, Pakistan \\ ${ }^{\mathrm{b}}$ Agricultural Research Institute (ARI), Tarnab Peshawar, KPK, Pakistan
}

(received January 6, 2018; revised August 17, 2018; accepted August 27, 2018)

\begin{abstract}
Olive (Olea europaea L.) and mandarin (Citrus reticulatae) have been used therapeutically for their nutraceutical and medicinal value. Olive juice contains high vitamin E and phenolic compounds. Similarly, mandarin is a rich source of vitamin C. Hence olive juice was blended with mandarin fruit juice for increasing the therapeutic, nutritional and functional value of Ready-to-Serve (RTS) beverages. Preliminary study revealed that Ready-to-Serve (RTS) product of olive mandarin (60:40) was highly acceptable on sensory basis by the panel of judges. Olive juice and mandarin juice were utilized at various combinations with sugar and artificial sweeteners (aspartame, sucralose and cyclamate) for preparation of therapeutic RTS beverages and evaluated for physico-chemical and sensory attributes during storage. The study revealed that the therapeutic RTS beverages prepared by blending of olive and mandarin juices with cyclamate has scored maximum for almost all sensorial quality attributes such as appearance, colour, flavour, taste and overall acceptability and also contained phenolic compounds, flavonoids and ascorbic acid in large quantity. A reducing trend was observed in ascorbic acid and increasing trend was observed in acidity content during the storage of beverage at room temperature over a period of 90 days. The beverage changed significantly with respect to TSS content along the storage period.
\end{abstract}

Keywords: olive fruit, artificial sweetener, mandarin, RTS, diet drink

\section{Introduction}

Ready-to-Serve (RTS) beverages, nectar etc can be made by mixing two or more fruit juices and pulp (Bhardwaj and Mukherjee, 2011; Jain and Khurdiya, 2005; Langthasa, 1999; Saxena et al., 1996; Sandhu and Sindhu, 1992). Ready-to-Serve fruit drink is a type of fruit beverage which contains at least $10 \%$ fruit and $10 \%$ total soluble solids besides approximately $0.3 \%$ acid, planned for consumption without dilution and prepared from unfermented pure fruit juice with or without some of the pulp and containing any soluble carbohydrate and water (Nilugin and Mahendran, 2010). According to (Otten et al., 2006) Mixing two or more fruits will create a novel flavour and taste. Recently blended beverages are available in different flavours such as orange, mango, strawberry, pineapple, chocolate, banana, raspberry and vanilla etc. Various blended beverages were prepared using guava papaya and mango and their storage stability was reported (Kalra et al., 1991; Kalra and Tandon, 1984).

Olive (Olea europaea L.) locally Zaitoon, an evergreen tree with greyish-green plants. It is a slow and steady

*Author for correspondence;

E-mail: arsalankhan.fst@gmail.com growing tree having a long life of about 900 to 1000 years (Simmonds, 1976). Olive is an evergreen tree native to western Asia, is extensively grown in the Mediterranean Basin, the subtropical regions of Australia, southern Africa and north and south America. Some 750 million trees are grown on approximately 8.5 million hectares of which about $97 \%$ are in Mediterranean countries (Nico et al., 2002). The olive tree and olive oil are mentioned seven times in the (Hassouna, 2010). The performance of project "promotion of olive cultivation for economic development and poverty alleviation" had initiated by Pakistan agricultural research council (PARC) that olive plants were cultivated on 300 hectares in Baluchistan, 100 hectares in Khyber Pakhtunkhwa, 300 hectares in federally administered tribal areas and about 100 hectares in the Pothohar area of Punjab. This project charged about Rs 382 millions and completed in three years which was under the Pakistan Italian dept for development swap agreement (Tahir, 2012). Olives are one of the most extensively cultivated fruit crops in the world (Nico, 2002). The world cultivated area of olives in 2009 was over 9.2 million ha with an average yield of 2.1 tonne/ha (FAO, 2011). 
Mandarin (Citrus reticulatae) is a citrus fruits having sweet taste, bright colour and appearance grown in Pakistan particularly in Khyber Pakhtunkhwa and Punjab. Mandarin locally known as kinnow, contributes more than $60 \%$ of country's citrus fruit (Altaf and Khan, 2009). Total kinnow production in Pakistan is about $342,390,991$ tonnes and the value of this production is about 14.563316 billion rupees (FVC statistics of Pakistan, 2012-2013).

Citrus is most commonly thought of as a good source of vitamin C. However, like most other whole foods, citrus fruits also contain an impressive list of other essential nutrients, including both glycemic and nonglycemic carbohydrate (sugars and fibre), potassium, folate, calcium, thiamin, niacin, vitamin $\mathrm{B}_{6}$, phosphorus, magnesium, copper, riboflavin, pantothenic acid and a variety of phytochemicals. In addition, citrus contains no fat or sodium and, being a plant food, no cholesterol. The average energy value of fresh citrus is also low (see Table), which can be very important for consumers concerned about putting on excess body weight. For example, a medium orange contains 60 to $80 \mathrm{kcal}$, a grapefruit $90 \mathrm{kcal}$ and a tablespoon $(15 \mathrm{~mL})$ of lemon juice only $4 \mathrm{kcal}$ (Whitney and Rolfes, 1999). Citrus fruit juice contains ascorbic acid in the range of 60 to $70 \mathrm{mg}$ (Fladae et al., 2003). Mandarin peel is also a good source of ascorbic acid, polyphenolic antioxidants and carotenoids, (Anwar et al., 2008). Citrus fruit quality can be identified by its physical appearance, colour, texture, size and also an internal properties juice, ascorbic acid, total soluble solids and titratable acidity (Ahmed, 2005). Citrus fruits are also used as an ingredient for value added products (Gorinstein et al., 2004; Nchez et al., 2003).

As olive fruit are blessing with huge amount of phenolic compound which make the olive fruit bitter in taste (oleuropein a phenolic compound) can be change to other compounds like hydroxy-tyrosol or tyrosol (Omar and Haris, 2010). A research study has been conducted on the waste water of milled olive and concluded that the waste water of olive has high phenolic compounds which has a great impact on quality of beverages and many others foods. This research was conducted, based on phenolic compounds which are related to the health of the consumer and related to the effect of processing and storage period of the components and preservation of the foods. As the wastewater is added in beverages to prevent many dangerous diseases has a significant aim (Hanna and Abbasi, 2012).
The aim of the study was to prepare a low caloric ready to serve drink from blend of kinnow and olive fruits to bring the olive fruit in mainstream beverages line which will ultimately benefited the grower and the consumer.

\section{Materials and Methods}

Healthy, sound and ripened mandarin were purchased from the Peshawar local market, while the ripened olive prepared pulp was taken from Food Technology Section of ARI, Tarnab Peshawar and brought both the fruits and olive pulp to the laboratory of Food Science and Technology Agriculture Research Institute, ARI, Tarnab Peshawar where research work was conducted.

Pre-processing. Olive has a bitter taste, which is due to a natural glucoside called oleuropein olive fruit were first dipped in $2 \%$ sodium hydroxide (Lye solution) for $36 \mathrm{~h}$ to remove the bitterness. The removal of oleuropein is tested with $1 \%$ phenolphthalein indicator which gives red colour. The lye is leached out from the olive fruit by washing in running water for $24 \mathrm{~h}$, the removal of lye is again test with $1 \%$ phenolphthalein giving no colour indicating that lye is completely removed from the olive fruit (Kemal and Cevdet, 2003).

After removal of bitterness from the olive fruit the pulp was obtained through pulper machine. Mandarin fruit were selected by an acceptable colour and size and cut manually, and its juice was extracted by pulper.

Storage. Three different artificial sweeteners such as sucralose, aspartame and cyclamate were used in different combination according to the plan of study except the $\mathrm{MOD}_{0}$ incorporated with sucrose. Chemical preservative i.e. sodium benzoate. The whole fruits juices were immersed in $250 \mathrm{~mL}$ sterilized plastic bottle filled up. The bottles were completely sealed and stored at room temperature for shelf life study and analysis. The effect of storage on physiochemical changes were analyzed by standard AOAC methods, while sensory analysis was done by using Larmond (1977) scale at an interval of 15 day for a total period of three months at room temperature.

Physico-chemical analysis. The samples were analyzed for $\mathrm{pH}$, total soluble solids, $\%$ acidity, ascorbic acid as described by AOAC, 2012 methods.

Sensory evaluation. The samples of olive and mandarin diet RTS were examined sensory for colour, texture, flavour rand overall acceptability by 10 judge's panel. Organoleptic study was carried out at the storage intervals 
of 15 days for a total period of 3 months. The evaluation was conceded out by using 9 points hedonic scale of Larmond (1977). Samples were offered to qualified judges to make comparison and to assign them score among 1-9.

Total phenolic component. A total phenolic content of ready to serve juice was determined by method of McDonald et al. (2001).

Reagents. There were different chemical compounds and chemical solvents which were required for standard curve preparation. These chemicals are Gallic acid, Sodium carbonate, Folin-ciocaltue, Ethanol.

Standard curve preparation. For standard curve preparation about $0.5 \mathrm{~g}$ Gallic acid was used and was mixed in $10 \mathrm{~mL}$ ethanol, and about $100 \mathrm{~mL}$ level was prepared with the addition of distilled water. For this curve different concentration of stock solution was prepared that was up to $5000 \mathrm{ppm}(1 \mathrm{ppm}=1 \mathrm{mg} / \mathrm{L})$ stock solution. After that the stock solution was made and then the secondary solution like $50 \mathrm{ppm}, 100 \mathrm{ppm}$ and $150 \mathrm{ppm}$ were prepared. $0.5 \mathrm{~mL}$ stock solution was used, and the volume was made up to $50 \mathrm{~mL}$ with distilled water this was $50 \mathrm{ppm}$ solution with 0.5 concentrations. Similarly, $1 \mathrm{~mL}$ of stock solution was used for 1.00 concentrations. $1.5 \mathrm{~mL}$ stock solution was taken, and the volume was made up to $50 \mathrm{~mL}$ with distilled water this was $150 \mathrm{ppm}$ solution with 1.5 concentrations.

Blank sample preparation. For blank sample preparation $4 \mathrm{~mL}$ distilled water and $1 \mathrm{~mL}$ folin-ciocaltue reagent was added with $5 \mathrm{~mL}$ of $20 \%$ sodium carbonate and were shaken vigorously, after shaking it was incubated at room temperature for $30 \mathrm{~min}$. Take the observation reading at $720 \mathrm{~nm}$ on spectrophotometer.

Sample procedure. From sample of olive mandarin blended diet RTS about1 $\mathrm{g}$ of quantity was used in 100 $\mathrm{mL}$ volumetric flask and $70 \mathrm{~mL}$ distilled water was added. And was boiled in hot sand bath for $30 \mathrm{~min}$ (when boiling started time was noted) after boiling the solution was filter with filter paper. The volume was made up to $50 \mathrm{~mL}$ with distilled water. After that 0.1 $\mathrm{mL}$ sample was extracted in test tube and was added with $3.9 \mathrm{~mL}$ distilled water and $1 \mathrm{~mL}$ folin-ciocaltue reagent added with $5 \mathrm{~mL}$ of $20 \%$ sodium carbonate. It was shaken vigorously; after shaking it was incubated at room temperature for $30 \mathrm{~min}$ and observes the reading at $720 \mathrm{~nm}$ on spectrophotometer. All process was occurred in dark place.

$$
\mathrm{Y}=\mathrm{MX}+\mathrm{B}
$$

where:

$\mathrm{Y}=$ Total absorption reading of spectrophotometer

$\mathrm{M}=$ Pure sample reading which is required

$\mathrm{X}=$ The slope of the graph

$\mathrm{B}=$ The intercept point

Total flavonoids. Total flavonoids was determined by aluminum chloride colorimetric method (Chang et al., 2002).

Reagents. The reagents used and required for this process are Quercetin, Aluminum chloride $\left(\mathrm{Al} \mathrm{Cl}_{3}\right)$, potassium acetate and methanol.

Standard curve preparation. For standard curve preparation quercetin stock solution was to make first. After that $1 \mathrm{~g}$ quercetin was taken and dissolved in 1 liter methanol or $0.1 \mathrm{~g} / 100 \mathrm{~mL}$ this was $1000 \mathrm{ppm}$ quercetin stock solution. After that secondary standard solution was prepared like $15 \mathrm{ppm}, 30 \mathrm{ppm}, 45 \mathrm{ppm}$ and $60 \mathrm{ppm}$ used quercetin stock solution and after that $0.75 \mathrm{~mL}$ quercetin stock solution was taken in a flask and volume was made up to $50 \mathrm{~mL}$ with the addition of methanol. This was $0.75 \mathrm{~mL}$ concentration then $1.5 \mathrm{~mL}$ quercetin stock solution was taken in a flask and volume was made up to $50 \mathrm{~mL}$ with the addition of methanol. This was $1.5 \mathrm{~mL}$ concentration and then $2.25 \mathrm{~mL}$ quercetin stock solution was taken in a flask and volume was made up to $50 \mathrm{~mL}$ with the addition of methanol. This was $2.25 \mathrm{~mL}$ concentration. Similarly, then $3 \mathrm{~mL}$ quercetin stock solution was taken in a flask and volume was made up to $50 \mathrm{~mL}$ with the addition of ethanol. This was $3 \mathrm{~mL}$ concentration. After that 4 test tubes were taken and from each flask $0.5 \mathrm{~mL}$ solution was added with $0.1 \mathrm{~mL} \mathrm{AlCl} 3(10 \%)$ and $1.5 \mathrm{~mL}$ methanol (pure) and $0.1 \mathrm{~mL}$ potassium acetate (1M) and $2.8 \mathrm{~mL}$ distilled water were taken. Total volume was $5 \mathrm{~mL}$ and O.D at $415 \mathrm{~nm}$ was taken on spectrophotometer.

Sample procedure. For sample procedure $1 \mathrm{~g}$ sample of olive mandarin blended diet drink was taken and was dissolved in $10 \mathrm{~mL}$ methanol extraction of plant material and was filtered and then $0.5 \mathrm{~mL}$ methanolic extract with $0.1 \mathrm{~mL} \mathrm{AlCl}_{3}(10 \%)$ added with $1.5 \mathrm{~mL}$ methanol (pure) and $0.1 \mathrm{~mL}$ potassium acetate $(1 \mathrm{M})$ and $2.8 \mathrm{~mL}$ distilled water were taken and were mixed. A sample blank was similarly prepared for each sample, but the same amount of sample was replaced by methanol. Total volume was $5 \mathrm{~mL}$ incubated at room temperature 
for $30 \mathrm{~min}$ and then O.D at $415 \mathrm{~nm}$ was taken on spectrophotometer and the formula is:

$$
\mathrm{Y}=\mathrm{MX}+\mathrm{B}
$$

where:

$\mathrm{Y}=$ Total absorption reading of spectrophotometer

$\mathrm{M}=$ Pure sample reading which is required

$\mathrm{X}=$ The slope of the graph

$\mathrm{B}=$ The intercept point

Statistical analysis. All the data concerning treatments and storage interval were statistically analyzed by means of completely Randomized Design (CRD) 2 Factorial and the means were separated by applying least significant difference (LSD) Test at 5\% possibility level as defined by Steel and Torrie (1997).

\section{Results and Discussion}

Total soluble solids. The statistical analysis showed that storage intervals and treatments had a significant $(\mathrm{P}<0.05)$ effect on TSS of olive and mandarin diet RTS (Table 1). Total soluble solid of all RTS samples were in the range of 1.5 to $1.8^{\circ}$ brix on fresh basis and was increased to 2 to $2.9^{\circ}$ brix after 90 days of storage.
Storage means revealed that TSS was significantly increased from 1.61 to $2.75^{\circ}$ brix. On the other hand, $\mathrm{MOD}_{0}$ had higher (2.42 brix) as it contains sucrose and rest of the samples contains non-caloric sweeteners. However, treatments mean shows that the highest mean value was recorded in $\mathrm{MOD}_{0}(2.42)$, while the lowest mean value was recorded in $\mathrm{MOD}_{3}(1.8)$. The highest change was occurred in $\mathrm{MOD}_{4}(48.38 \%)$, while the lowest change was occurred in $\mathrm{MOD}_{3}(28.57 \%)$. These results are in conformity with the work Zeb et al. (2008) who determined the increase occurred in TSS in grape juice stored at ambient temperature significantly. These results have the similarities with the findings of Rodrique (2003) that reported the total soluble solids of blended orange and carrot juice increased throughout storage. Gillani (2002) also approved that there was increase in TSS of mango squash prepared from different mango cultivars. Kinh et al. (2001) reported an increase in TSS of apple pulp preserved with chemical preservative. Shah et al. (1975) mentioned that increase in soluble content of the product may be due to the solubilization of fruit constituents for the duration of storage which is shown in Table 2 .

Table 1. Proposed plane of study treatments of diet RTS

\begin{tabular}{|c|c|c|c|c|c|c|c|c|}
\hline Sample & $\begin{array}{l}\text { Mandarin } \\
(\mathrm{mL})\end{array}$ & $\begin{array}{l}\text { Olive pulp } \\
(\mathrm{mL})\end{array}$ & $\begin{array}{l}\text { CMC } \\
(\mathrm{g})\end{array}$ & $\begin{array}{l}\text { Water } \\
(\mathrm{mL})\end{array}$ & $\begin{array}{l}\text { Sucralose } \\
(\mathrm{g})\end{array}$ & $\begin{array}{l}\text { Aspartame } \\
\text { (g) }\end{array}$ & $\begin{array}{l}\text { Cyclamate } \\
(\mathrm{g})\end{array}$ & $\begin{array}{l}\text { Sucrose } \\
(\mathrm{g})\end{array}$ \\
\hline $\mathrm{MOD}_{0}$ & 200 & 300 & 2.5 & 2000 & & - & & 375 \\
\hline $\mathrm{MOD}_{1}$ & 200 & 300 & 2.5 & 2000 & $\overline{0} .625$ & - & - & - \\
\hline $\mathrm{MOD}_{2}$ & 200 & 300 & 2.5 & 2000 & 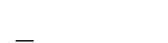 & $\overline{1} .875$ & & - \\
\hline $\mathrm{MOD}_{3}$ & 200 & 300 & 2.5 & 2000 & - & & $\overline{1} 2$ & - \\
\hline $\mathrm{MOD}_{4}$ & 200 & 300 & 2.5 & 2000 & $\overline{0} .313$ & $\overline{0} .94$ & & - \\
\hline $\mathrm{MOD}_{5}$ & 200 & 300 & 2.5 & 2000 & 0.313 & & $\overline{6}$ & - \\
\hline $\mathrm{MOD}_{6}$ & 200 & 300 & 2.5 & 2000 & - & $\overline{0} .94$ & 6 & - \\
\hline
\end{tabular}

Table 2. Effect of storage intervals and treatments on total soluble solids ( ${ }^{\circ}$ brix) of olive and mandarin diet RTS

\begin{tabular}{|c|c|c|c|c|c|c|c|c|c|}
\hline \multirow{3}{*}{ Treatment } & \multicolumn{9}{|c|}{ Storage interval (days) } \\
\hline & 0 & 15 & 30 & 45 & 60 & 75 & 90 & $\%$ Increase & Mean \\
\hline & \multicolumn{9}{|c|}{ Total soluble solid ( ${ }^{\circ}$ brix $)$} \\
\hline $\mathrm{MOD}_{0}$ & 13.2 & 13.3 & 13.5 & 13.7 & 13.9 & 14.1 & 14.3 & 7.69 & $13.71 \mathrm{a}$ \\
\hline $\mathrm{MOD}_{1}$ & 1.7 & 1.9 & 2.1 & 2.2 & 2.4 & 2.6 & 2.8 & 39.28 & $2.24 \mathrm{c}$ \\
\hline $\mathrm{MOD}_{2}$ & 1.6 & 1.8 & 2 & 2.1 & 2.3 & 2.4 & 2.5 & 36 & $2.1 \mathrm{de}$ \\
\hline $\mathrm{MOD}_{3}$ & 1.5 & 1.6 & 1.7 & 1.8 & 1.9 & 2 & 2.1 & 28.57 & $1.8 \mathrm{f}$ \\
\hline $\mathrm{MOD}_{4}$ & 1.6 & 1.9 & 2.2 & 2.5 & 2.7 & 2.9 & 3.1 & 48.38 & $2.41 b$ \\
\hline $\mathrm{MOD}_{5}$ & 1.5 & 1.6 & 1.8 & 2.1 & 2.3 & 2.5 & 2.7 & 44.44 & $2.07 \mathrm{e}$ \\
\hline $\mathrm{MOD}_{6}$ & 1.6 & 1.8 & 2 & 2.2 & 2.4 & 2.6 & 2.9 & 44.82 & $2.21 \mathrm{~cd}$ \\
\hline Mean & $3.24 \mathrm{~g}$ & $3.41 \mathrm{f}$ & $3.61 \mathrm{e}$ & $3.8 \mathrm{~d}$ & $3.98 \mathrm{c}$ & $4.15 b$ & $4.34 a$ & & \\
\hline
\end{tabular}

Means with different letters are significantly $(\mathrm{P}<0.05)$ different from each other. 
pH. Table 3 presents the effect of different sweeteners and storage interval on $\mathrm{pH}$ of mandarin and olive blended RTS. Both storage interval and different sweeteners had significantly $(\mathrm{P}<0.05)$ effect the $\mathrm{pH}$ of mandarin and olive blended RTS. The $\mathrm{pH}$ of all fresh samples were in the range of 3.26 to 3.7. After 90 days of storage of $\mathrm{pH}$ of all the samples were decreased gradually in the range of 2.5-3. Storage mean values shows that $\mathrm{pH}$ value significantly $(\mathrm{P}<0.05)$ decreased from 3.27 to 2.85. In case of treatments the highest mean value was recorded in sample $\mathrm{MOD}_{5}$ and $\mathrm{MOD}_{1}$ (3.17), while the lowest mean value was found out in sample $\mathrm{MOD}_{4}$ (2.94). This is also observed that during storage the highest loss in $\mathrm{pH}$ was occurred in sample $\mathrm{MOD}_{4}$ $(23.78 \%)$, while the lowest change throughout the storage was occurred in sample $\mathrm{MOD}_{3}(7.97 \%)$. Similar results were obtained by Zeb et al. (2008) who reported that $\mathrm{pH}$ decreases during processing and storage of grape juice. The decrease in $\mathrm{pH}$ is due to increase in acidity during storage period. Our results are in similarity to those of Cecilia and Maia (2002) who observed a decrease in $\mathrm{pH}$ of high pulp content apple juice during storage. This decrease may be due to the formation of acid and pectin hydrolysis (Imran et al. 2000). Similarly, Saini and pal (1996) found that the decrease in $\mathrm{pH}$ of kinnow juice might be due to acidic compound formed by the degradation of reducing sugar and pectin.

Titratable acidity. Acidity is an important attribute due to the tartness which is a major factor in the acceptability of beverages. As the $\mathrm{pH}$ decreased there was a proportional increase in acidity during storage of grape juice. Throughout the storage the titratable acidity of olive and mandarin diet RTS has been affected $(\mathrm{P}<0.05)$ significantly. At the first day the titratable acidity of samples $\left(\mathrm{MOD}_{0}\right.$ to $\mathrm{MOD}_{6}$ ) was ranged 0.41 to 0.44 which regularly increased throughout 90 days of storage. The mean values for titratable acidity significantly $(\mathrm{P}<0.05)$ increased from 0.45 to 0.59 throughout storage. Maximum mean values were recorded in sample $\mathrm{MOD}_{0}, \mathrm{MOD}_{1}$ and $\mathrm{MOD}_{5}(0.55)$, while minimum mean values were found in sample $\mathrm{MOD}_{4}(0.45)$. The highest change was occurred in sample $\mathrm{MOD}_{0}(34.92 \%)$, while the lowest change effect was found in sample $\mathrm{MOD}_{3}$ $(15.52 \%)$ as shown in Table 4. According to the results of Mehmood et al. (2008) also determined the acidity in fruit juices increase and $\mathrm{pH}$ decreases during processing and storage. Radriqo et al. (2003) and Sandhu (2001) observed an increase in titratable acidity of kinow juice during storage. The increase in acidity could be due to formation of acidic compounds or oxidation of reducing sugar present in the juice. Similarly Cecilia and Maia (2002) reported an increase in titratable acidity of apple juice. This increase could be due to high storage temperature or break down of pectic bodies into acid (Riaz et al., 1983).

Ascorbic acid. The result of ascorbic acid has showed in Table 5 in which the storage intervals and the treatments had significantly $(\mathrm{P}<0.05)$ effected. Initially the amount of ascorbic acid of samples $\left(\mathrm{MOD}_{0}\right.$ to $\mathrm{MOD}_{6}$ ) was recorded as 35 to $37 \mathrm{mg} / 100 \mathrm{~g}$ and as a result it regularly decreased to the last reading i.e. 18.5 throughout the 90 days of storage period. The mean values of ascorbic acid amount significantly decreased from 36.01 to $19.78 \mathrm{mg} / 100$ gin storage. For treatments the highest mean values were observed in sample $\mathrm{MOD}_{4}$ $(29 \mathrm{mg} / 100 \mathrm{~g})$. The lowest mean values were found out in sample $\mathrm{MOD}_{0}(26.62 \mathrm{mg} / 100 \mathrm{~g})$, the maximum change occurred in sample $\mathrm{MOD}_{0}(51.38 \%)$, while the

Table 3. Effect of storage and treatments on the $\mathrm{pH}$ of olive and mandarin diet RTS

\begin{tabular}{|c|c|c|c|c|c|c|c|c|c|}
\hline \multirow{3}{*}{ Treatment } & \multicolumn{9}{|c|}{ Storage interval (days) } \\
\hline & 0 & 15 & 30 & 45 & 60 & 75 & 90 & $\%$ Increase & Mean \\
\hline & \multicolumn{9}{|c|}{ Total soluble solid ( ${ }^{\circ}$ brix $)$} \\
\hline $\mathrm{MOD}_{0}$ & 3.29 & 3.25 & 3.2 & 3.16 & 3.12 & 3.1 & 3 & 8.81 & $3.16 \mathrm{ab}$ \\
\hline $\mathrm{MOD}_{1}$ & 3.28 & 3.26 & 3.23 & 3.21 & 3.2 & 3.1 & 2.9 & 11.58 & $3.17 \mathrm{ab}$ \\
\hline $\mathrm{MOD}_{2}$ & 3.27 & 3.25 & 3.22 & 3.2 & 3 & 2.9 & 2.7 & 17.43 & $3.07 \mathrm{~b}$ \\
\hline $\mathrm{MOD}_{3}$ & 3.26 & 3.25 & 3.24 & 3.23 & 3.22 & 3.21 & 3 & 7.97 & $3.2 \mathrm{a}$ \\
\hline $\mathrm{MOD}_{4}$ & 3.28 & 3.23 & 3.2 & 3 & 2.8 & 2.6 & 2.5 & 23.78 & $2.94 \mathrm{c}$ \\
\hline $\mathrm{MOD}_{5}$ & 3.29 & 3.25 & 3.21 & 3.18 & 3.15 & 3.11 & 3 & 8.81 & $3.17 \mathrm{ab}$ \\
\hline $\mathrm{MOD}_{6}$ & 3.27 & 3.22 & 3.19 & 3.15 & 3.12 & 3.1 & 2.9 & 11.31 & $3.13 \mathrm{ab}$ \\
\hline Mean & $3.27 \mathrm{a}$ & $3.24 \mathrm{ab}$ & $3.21 \mathrm{ab}$ & $3.16 b c$ & $3.08 \mathrm{~cd}$ & $3.01 \mathrm{~d}$ & $2.85 \mathrm{e}$ & & \\
\hline
\end{tabular}

Means with different letters are significantly $(\mathrm{P}<0.05)$ different from each other. 
Table 4. Effect of storage intervals and treatments on acidity of olive and mandarin diet RTS

\begin{tabular}{llllllllll}
\hline \hline & \multicolumn{8}{c}{ Storage interval (days) } \\
\cline { 2 - 10 } & 0 & 15 & 30 & 45 & 60 & 75 & 90 & \% Increase & Mean \\
\cline { 2 - 9 } & 0.41 & 0.53 & 0.55 & 0.57 & 0.59 & 0.60 & 0.63 & 34.92 & $0.55 \mathrm{a}$ \\
MOD $_{0}$ & 0.48 & 0.51 & 0.54 & 0.56 & 0.58 & 0.59 & 0.61 & 21.31 & $0.55 \mathrm{a}$ \\
MOD $_{1}$ & 0.46 & 0.48 & 0.51 & 0.54 & 0.55 & 0.57 & 0.60 & 23.33 & $0.53 \mathrm{ab}$ \\
MOD $_{3}$ & 0.49 & 0.50 & 0.51 & 0.52 & 0.53 & 0.55 & 0.58 & 15.52 & $0.53 \mathrm{bc}$ \\
MOD $_{4}$ & 0.38 & 0.40 & 0.42 & 0.45 & 0.47 & 0.49 & 0.51 & 25.49 & $0.45 \mathrm{bc}$ \\
MOD $_{6}$ & 0.46 & 0.50 & 0.54 & 0.55 & 0.57 & 0.59 & 0.61 & 24.49 & $0.55 \mathrm{c}$ \\
\hline Mean & 0.44 & 0.46 & 0.51 & 0.53 & 0.55 & 0.57 & 0.59 & 25.42 & $0.52 \mathrm{~d}$ \\
\hline \hline
\end{tabular}

Means with different letters are significantly $(\mathrm{P}<0.05)$ different from each other.

Table 5. Effect of storage intervals and treatments on ascorbic acid of olive and mandarin diet RTS

\begin{tabular}{|c|c|c|c|c|c|c|c|c|c|}
\hline \multirow{3}{*}{ Treatment } & \multicolumn{9}{|c|}{ Storage interval (days) } \\
\hline & 0 & 15 & 30 & 45 & 60 & 75 & 90 & $\%$ Increase & Mean \\
\hline & \multicolumn{9}{|c|}{ Total soluble solid ( ${ }^{\circ}$ brix $)$} \\
\hline $\mathrm{MOD}_{0}$ & 36 & 33 & 30 & 26.5 & 23.4 & 20 & 17.5 & 51.38 & $26.62 \mathrm{c}$ \\
\hline $\mathrm{MOD}_{1}$ & 36.1 & 34.3 & 32.2 & 30 & 26 & 23 & 20.5 & 43.21 & $28.87 \mathrm{a}$ \\
\hline $\mathrm{MOD}_{2}$ & 35.5 & 33 & 31 & 29 & 26 & 24 & 21 & 40.84 & $28.5 \mathrm{ab}$ \\
\hline $\mathrm{MOD}_{3}$ & 36 & 34 & 31.5 & 28.5 & 26.2 & 24.5 & 22 & 38.88 & $28.95 \mathrm{a}$ \\
\hline $\mathrm{MOD}_{4}$ & 36.5 & 34.5 & 32 & 29 & 27 & 24 & 20 & 45.2 & $29 \mathrm{a}$ \\
\hline $\mathrm{MOD}_{5}$ & 35 & 33 & 31 & 29 & 25 & 22 & 19 & 45.71 & $27.71 b$ \\
\hline $\mathrm{MOD}_{6}$ & 37 & 34 & 31.5 & 28 & 24 & 21 & 18.5 & 50 & $27.71 b$ \\
\hline Mean & $36.01 \mathrm{a}$ & $33.68 b$ & $31.31 \mathrm{c}$ & $28.57 \mathrm{~d}$ & $25.37 \mathrm{e}$ & $22.64 f$ & $19.78 \mathrm{~g}$ & & \\
\hline
\end{tabular}

Means with different letters are significantly $(\mathrm{P}<0.05)$ different from each other.

lowest change was found in the sample $\mathrm{MOD}_{3}(38.88 \%)$. These results are related closely with the findings of Kinh et al. (2001) who studied a decrease in ascorbic acid content in apple pulp. The losses in ascorbic acid may occur due to the high temperature and light during storage. Mehmood et al. (2008) had observed a result of an experiment on apple juice and found that ascorbic acid decreased in juice during storage period. Zeb et al. (2008) also conducted an experiment on grape juice and determined that ascorbic acid decreased in the juice during storage under the room temperature.

Phenols content in RTS (mgGAE/g). The effect of treatments and different sweeteners on the total phenol components has showed in the Figure. The total polyphenols were studied in olive and mandarin diet drinks in all the samples $\left(\mathrm{MOD}_{0}\right.$ to $\left.\mathrm{MOD}_{6}\right)$ such as $70.8,60.3$, $63.2,62,63.4,64.5$ and $61.5 \mathrm{mg} \mathrm{GAE} / \mathrm{g}$ in which the maximum amount of phenols was found in the sample $\mathrm{MOD}_{0}(70.8 \mathrm{mg} / \mathrm{g})$, while the minimum quantity of phenols was found in sample $\mathrm{MOD}_{1}$ (60.3). PerezMartinez et al. (2010) reported that the total phenolic compounds found in different types of coffees ranged from 60 to $70 \mathrm{mg} / \mathrm{g}$. According to Lopez-Galilea et al. (2007) the addition of sugar stimulates the formation of melanoidins, which can react with the FolinCiocalteu reagent increasing the value of total phenols. Srividya and Ramachandran (2012) have got the same result of polyphenols in papaya RTS spiced beverage.

Flavonoids contents in RTS (mgQE/g). The effect of treatments different artificial sweeteners on flavonoids was observed in olive and mandarin diet drink in the samples $\left(\mathrm{MOD}_{0}\right.$ to $\left.\mathrm{MOD}_{6}\right)$ such as $30.54,40.33,45.45$, 51.52 , 44.23, 40.43 and $35.36 \mathrm{mg} \mathrm{QE} / \mathrm{g}$, respectively. In which the maximum value was found in $\mathrm{MOD}_{3}$ (51.52), while the minimum value was found in $\mathrm{MOD}_{0}$ (30.54) which has mentioned in the following graph in Fig. 1. Wu, et al. (2007) determined the total flavonoids in grape fruit peel and juice in the quantity of 40 to 
$50 \mathrm{mg} / \mathrm{g}$. Oszmianski and Wojdylo (2009) found a loss from 37.28 to $50.50 \%$ of flavanols in apple juice after 6 months storage at $30{ }^{\circ} \mathrm{C}$.

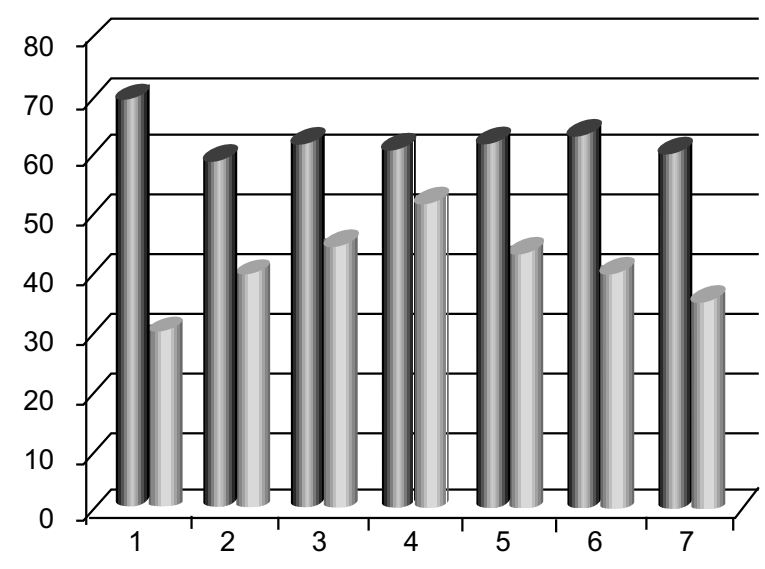

Phenols Flavinoids

Fig. 1. Effect of treatments on phenols (mg GAE/g) and flavonoids (mg QE/g) components in olive and mandarin diet RTS ( $\mathrm{x}$-axis represents the storage intervals and the $y$-axis represents the $\mathrm{mg} / \mathrm{g}$ ).

Organoleptic evaluation. All the RTS samples were evaluated sensory for color, flavor, taste, and overall acceptability by using 9 point hedonic scale of Larmond (1977).

Colour. The statistical analysis revealed that the storage intervals and treatments had a significant $(\mathrm{P}<0.05)$ effect on the colour of diet RTS. Firstly the mean score of judges for colour of all samples was in the range of 8 to 8.3 which was slowly decreased to 6.1 throughout the storage. The whole mean score of the judges for color significantly changed from 6.12 to 6.11 throughout the storage. For treatments, the highest mean value was observed in sample $\mathrm{MOD}_{3}$ (7.68), while the lowest mean value was in the sample $\mathrm{MOD}_{0}(6.84)$. The highest change (decrease) was occurred in sample $\mathrm{MOD}_{0}$ (28.04\%), while the lowest change was occurred in sample $\mathrm{MOD}_{3}(15.66 \%)$ as shown in Table 6 . This deprivation of the appearance may be due to the physicochemical changes by poverty of the chlorophyll and increased in carotenoid pigments throughout the storage. This may be due to some principal agents which are accountable for degradation such as oxidative system, PH change and enzymes like chlorophyllases (Gowada and Huddar, 2001; Wills et al. 1982). Its root cause may also be the restricted moisture and weight loss. These results are related with the study of Brennder et al. (1985) who determined that $\mathrm{SO}_{2}$ reduces browning of fruits and vegetables.

Taste. In organoleptic evaluation taste is very important factor after colour. Table 7 presents the effect of different sweeteners and storage interval on taste of mandarin and olive blended RTS. Both storage interval and different sweeteners had significantly $(\mathrm{P}<0.05)$ effect the taste of mandarin and olive blended RTS. Firstly, the mean score of judges for taste of all samples was in the range of 7.8 to 8.2 and as a result the scores were decreased to the last score i.e. 5.8 throughout 90 days of storage. The mean scores totally of judges for taste significantly decreased from 8.02 to 5.64 during storage. For treatments, the highest mean value was stated in sample $\mathrm{MOD}_{1}$ (7.2). While the lowest mean score was stated in $\mathrm{MOD}_{0}$ (4.92) throughout the storage. The highest change was recorded in sample $\mathrm{MOD}_{0}(55.12 \%)$,

Table 6. Effect of storage intervals and treatments on colour of olive and mandarin diet RTS

\begin{tabular}{llllllllll}
\hline & \multicolumn{7}{c}{ Storage interval (days) } \\
\cline { 2 - 9 } Treatment & 0 & 15 & 30 & 45 & 60 & 75 & 90 & \% dec & Mean \\
\cline { 2 - 9 } & 8.3 & 8 & 7.9 & 7.8 & 7.5 & 7.3 & 7 & 15.66 & $7.68 \mathrm{a}$ \\
MOD $_{0}$ & 8.1 & 7.7 & 7.3 & 7 & 6.6 & 6.2 & 6 & 25.92 & $6.98 \mathrm{bc}$ \\
MOD $_{1}$ & 8 & 7.6 & 7.3 & 7 & 6.4 & 6 & 6 & 25 & $6.9 \mathrm{c}$ \\
MOD $_{2}$ & 8.2 & 7.4 & 7 & 6.8 & 6.4 & 6.2 & 5.9 & 28.04 & $6.84 \mathrm{c}$ \\
MOD $_{3}$ & 8.1 & 7.7 & 7.4 & 7 & 6.6 & 6.2 & 5.9 & 27.16 & $6.98 \mathrm{bc}$ \\
MOD $_{4}$ & 8.2 & 7.8 & 7.4 & 7.1 & 6.8 & 6.3 & 6 & 26.82 & $7.08 \mathrm{~b}$ \\
MOD $_{5}$ & 8 & 7.7 & 7.5 & 7.2 & 6.8 & 6.3 & 6.1 & 23.75 & $7.08 \mathrm{~b}$ \\
\hline MOD $_{6}$ & $6.12 \mathrm{a}$ & $7.7 \mathrm{~b}$ & $7.4 \mathrm{c}$ & $7.12 \mathrm{~d}$ & $6.72 \mathrm{e}$ & $6.35 \mathrm{f}$ & $6.11 \mathrm{~g}$ & & \\
\hline Mean & &
\end{tabular}

Means with different letters are significantly $(\mathrm{P}<0.05)$ different from each other. 
while the lowest change was occurred in sample $\mathrm{MOD}_{3}$ $(23.74 \%)$. These results are in line with the result of Hanger et al. (1996) that a lot of changes among sweeteners and blends were attributed to taste. Mixing of two or more sweeteners made the blend closer to sucrose by degrading side taste related with the individual sweeteners. Related results were found out by Martin, et al. (1995), who observed the decrease in sensory qualities of pasteurized orange juice bottled in clear glass bottles. Cohen et al. (1990) reported that TSS or acid is increased with the passage of time.

Flavour. The data regarding flavour in different treatment of diet drink is shown in Table 8, which is significantly $(\mathrm{P}<0.05)$ affected by storage intervals and different sweeteners used in different treatments of olive and mandarin diet drink. The first mean score for flavour of all samples was in range as 7.8 to 8.2 which were slowly decreased to the last score i.e. 5.4 throughout the storage. The totally mean scores of judges for flavour significantly decreased from 8.05 to 5.65 throughout the storage period. For treatments large mean values were observed in $\mathrm{MOD}_{3}$ (7.57). In storage, a large change was occurred in $\mathrm{MOD}_{0}(48.71 \%$ ), while the lowest change was occurred in sample $\mathrm{MOD}_{3}(17.07 \%)$. Same result was found by Ayub and Bilal (2001), who revealed that light has marked effect on flavour of pomegranate syrup. Through the conformation with the study of Kinh et al. (2001) who determined that apple pulp preserved with chemical preservatives sustain good flavour throughout the storage. Same results were obtained by Martin et al. (1995) who observed that the variation in sensory qualities of pasteurized orange juice was bottled in clear glass bottles. The accumulation of furfural level during storage was a good indicator of the off-flavour development in orange juice. Poll (1983) has also reported the similar trend of deterioration in flavour during storage in apple juice.

Overall acceptability. The statistical analysis showing that storage intervals and treatments had a significant

Table 7. Effect of storage intervals and treatments on taste of olive and mandarin diet RTS

\begin{tabular}{|c|c|c|c|c|c|c|c|c|c|}
\hline \multirow{3}{*}{ Treatment } & \multicolumn{9}{|c|}{ Storage interval (days) } \\
\hline & $\overline{0}$ & 15 & 30 & 45 & 60 & 75 & 90 & $\% \operatorname{dec}$ & Mean \\
\hline & \multicolumn{9}{|c|}{ Taste score } \\
\hline $\mathrm{MOD}_{0}$ & 8 & 7.8 & 7.5 & 7.2 & 7 & 6.7 & 6.1 & 23.74 & $7.18 \mathrm{a}$ \\
\hline $\mathrm{MOD}_{1}$ & 8.2 & 7.9 & 7.7 & 7.3 & 6.9 & 6.4 & 6 & 26.82 & $7.2 \mathrm{a}$ \\
\hline $\mathrm{MOD}_{2}$ & 8.1 & 7.7 & 7.3 & 7 & 6.7 & 6.3 & 6 & 25.92 & $7.01 \mathrm{a}$ \\
\hline $\mathrm{MOD}_{3}$ & 7.8 & 5.6 & 5.1 & 4.6 & 4.2 & 3.7 & 3.5 & 55.12 & $4.92 \mathrm{~b}$ \\
\hline $\mathrm{MOD}_{4}$ & 8 & 7.5 & 7.2 & 7 & 6.7 & 6.2 & 6.1 & 23.75 & $6.95 \mathrm{a}$ \\
\hline $\mathrm{MOD}_{5}$ & 8.1 & 7.7 & 7.5 & 7.1 & 6.8 & 6.5 & 6 & 25.92 & $7.1 \mathrm{a}$ \\
\hline $\mathrm{MOD}_{6}$ & 8 & 7.5 & 7.3 & 7 & 6.6 & 6.2 & 5.8 & 27.5 & $6.91 \mathrm{a}$ \\
\hline Mean & $8.02 \mathrm{a}$ & $7.38 \mathrm{~b}$ & $7.08 \mathrm{bc}$ & $6.74 \mathrm{~cd}$ & $6.41 \mathrm{~d}$ & $6 \mathrm{e}$ & $5.64 \mathrm{e}$ & & \\
\hline
\end{tabular}

Means with different letters are significantly $(\mathrm{P}<0.05)$ different from each other.

Table 8. Effect of storage intervals and treatments on flavour of olive and mandarin diet RTS

\begin{tabular}{llllllllll}
\hline \hline & \multicolumn{7}{c}{ Storage interval (days) } \\
\cline { 2 - 10 } Treatment & 0 & 15 & 30 & 45 & 60 & 75 & 90 & \% dec & Mean \\
\cline { 2 - 9 } & \multicolumn{7}{c}{ Flavour score } \\
\hline $\mathrm{MOD}_{0}$ & 8.2 & 8 & 7.8 & 7.6 & 7.4 & 7.2 & 6.8 & 17.07 & $7.57 \mathrm{a}$ \\
$\mathrm{MOD}_{1}$ & 8 & 7.7 & 7.2 & 6.9 & 6.5 & 6.1 & 5.8 & 27.5 & $6.88 \mathrm{~b}$ \\
$\mathrm{MOD}_{2}$ & 8.1 & 7.8 & 7.2 & 6.5 & 6.2 & 6 & 6 & 25.92 & $6.82 \mathrm{~b}$ \\
$\mathrm{MOD}_{3}$ & 7.8 & 6.5 & 6 & 5.5 & 5 & 4.5 & 4 & 48.71 & $5.61 \mathrm{c}$ \\
$\mathrm{MOD}_{4}$ & 8 & 7.6 & 7.2 & 6.8 & 6.4 & 6.2 & 6.1 & 23.75 & $6.9 \mathrm{~b}$ \\
$\mathrm{MOD}_{5}$ & 8.2 & 7.5 & 7.1 & 6.7 & 6.2 & 5.9 & 5.5 & 32.92 & $6.72 \mathrm{~b}$ \\
$\mathrm{MOD}_{6}$ & 8.1 & 7.7 & 7.4 & 7 & 6.5 & 6 & 5.4 & 33.33 & $6.87 \mathrm{~b}$ \\
\hline Mean & $8.05 \mathrm{a}$ & $7.54 \mathrm{~b}$ & $7.12 \mathrm{c}$ & $6.71 \mathrm{~d}$ & $6.31 \mathrm{e}$ & $5.98 \mathrm{f}$ & $5.65 \mathrm{~g}$ & & \\
\hline \hline
\end{tabular}

Means with different letters are significantly $(\mathrm{P}<0.05)$ different from each other. 
Table 9. Effect of storage intervals and treatments on over all acceptability of olive and mandarin diet RTS

\begin{tabular}{|c|c|c|c|c|c|c|c|c|c|}
\hline \multirow{3}{*}{ Treatment } & \multicolumn{9}{|c|}{ Storage interval (days) } \\
\hline & 0 & 15 & 30 & 45 & 60 & 75 & 90 & $\% \mathrm{dec}$ & Mean \\
\hline & \multicolumn{9}{|c|}{ Overall acceptability score } \\
\hline $\mathrm{MOD}_{0}$ & 8.1 & 8 & 7.7 & 7.5 & 7.4 & 7.2 & 7 & 13.58 & $7.55 \mathrm{a}$ \\
\hline $\mathrm{MOD}_{1}$ & 8 & 7.7 & 7.2 & 7 & 6.6 & 6 & 6 & 25 & $6.92 \mathrm{~cd}$ \\
\hline $\mathrm{MOD}_{2}$ & 8.1 & 7.6 & 7 & 6.5 & 6 & 5.5 & 5 & 38.27 & $6.52 \mathrm{~d}$ \\
\hline $\mathrm{MOD}_{3}$ & 7.8 & 7 & 6.2 & 5.3 & 4.6 & 4 & 3.7 & 52.56 & $5.51 \mathrm{e}$ \\
\hline $\mathrm{MOD}_{4}$ & 8.1 & 8 & 7.7 & 7.5 & 7.2 & 6.9 & 6.7 & 17.28 & $7.44 a b$ \\
\hline $\mathrm{MOD}_{5}$ & 8 & 7.7 & 7.3 & 7 & 6.8 & 6.4 & 6 & 25 & $7.02 b c$ \\
\hline $\mathrm{MOD}_{6}$ & 8 & 7.8 & 7.5 & 7 & 6.4 & 6 & 6.5 & 18.75 & $7.02 \mathrm{bc}$ \\
\hline Mean & $8.01 \mathrm{a}$ & $7.68 \mathrm{a}$ & $7.22 \mathrm{~b}$ & $6.82 \mathrm{bc}$ & $6.42 \mathrm{~cd}$ & $6 \mathrm{de}$ & $5.84 \mathrm{e}$ & & \\
\hline
\end{tabular}

Means with different letters are significantly $(\mathrm{P}<0.05)$ different from each other.

$(\mathrm{P}<0.05)$ effect on the overall acceptability of olive and mandarin diet RTS in storage period. The first mean score of judges for whole acceptability of all samples were in range as 7.8 to 8.1 and as a result the scores were slowly decreased up to the last reading i.e. 6.5 throughout the 90 days storage. The overall mean values of the judges for the all acceptability significantly $(\mathrm{P}<0.05)$ changed from 8.01 to 5.84 in the storage. For treatments, the highest mean value was stated in sample $\mathrm{MOD}_{3}$ (7.55), while the lowest mean value was recorded in sample $\mathrm{MOD}_{0}$ (5.51). During storage, the highest change was occurred in sample $\mathrm{MOD}_{0}(52.56 \%)$, while the lowest change was occurred in sample $\mathrm{MOD}_{3}$ (13.58\%) as shown in Table 9. Rosario (1996) examined that changing storage time and temperature make degradation of ascorbic acid and furfural production as described by Shimoda and Osajima (1981) gradually which leads to decrease in overall acceptability.

\section{Conclusion}

In the present investigation, it has been concluded to prepare and standardize the method for low calorie olive and mandarin based beverage. The nutritious beverages with better storage life could be developed by addition of olive and mandarin to a certain extent. After preparation, the quality of product was evaluated with the help of various experiments, like total soluble solids, phenols and flavonoids, ascorbic acid, $\mathrm{pH}$ etc. Some changes were occurred in physiochemical properties were examined but these changes did not affect the product considerably and the quality of product was found good for a 90 day. Low calorie therapeutic RTS prepared by olive and mandarin by using the artificial sweeteners like cyclamate proved to be the best among samples prepared and found to be organoleptically most acceptable. The sweetness of the product seems to be a highly appreciated characteristic that must be related to the consumer habits. This will also provide opportunity to olive growers to market their fruits as well as will increase the choice for manufacturer in terms of valuable raw material for their products.

Conflict of Interest. The authors declare that there is no conflict of interest.

\section{References}

Ahmed, W. 2005. Biophysical studies of scion stock compatibility in "Kinnow mandarin" (Citrus reticulata Blanco). In: Ph.D. Thesis. University of Agriculture Faisalabad, Pakistan, 221 pp.

Altaf, N., Khan, A.R. 2009. Growth and development of low seeded 'Kinnow' mandarin fruits in dense plantation. Journal of Agricultural Science and Technology, 11: 191-198.

Anwar, F., Naseer, R., Bhanger, M.I., Ashraf, S., Talpur, F.N., Aladededune, F.A. 2008. Physico-chemical characteristics of citrus seeds and oils from Pakistan. Journal of the American Oil Chemists Society, 8: 321-330.

AOAC, 2012. Official Method of Analysis. The Assoc. Official Analy. Chemists $19^{\text {th }}$ eds. Arlington USA.

Ayub, M., Khan, M.B. 2001. Effect of different light conditions and colored glass bottles on the retention of quality characteristics of pomegranate syrup during storage at room temperature. Sarhad Journal of Agriculture, 17: 629-632.

Bhardwaj, R.L., Mukherjee, S. 2011. Effects of fruit juice blending ratios on kinnow juice preservation 
at ambient storage condition. African Journal of Food Sciences, 5: 281-286.

Brennder, Kennedy, C.O., Oswin, D.S., Trim, G., Mrema, C., Werek, C. 1985. Solar dries and their role in post-harvest processing. Common Wealth Science Council, 78-83.

Cecilia, E., Maia, G.A. 2002. Storage stability of cashew apple juice preserved by hot fill and aseptic process. Department of food technology, University of Ceara, Brazil CEP, 60: 511-110.

Chang, C.C., Yang, M.H., Wen, H.M., Chern, J.C. 2002. Estimation of total flavonoid content in propolis by two complementary colourimetric methods. Journal of Food and Drug Analysis, 10: 178-182.

Cohen, E., Shalom, Y., Rosenburger, I. 1990. Post harvest ethanol buildup and off-flavour in 'Murcott' tangerine fruits. Journal of the American Society of Horticultural Science, 115: 775-778.

FVC, 2013. Kinow Production in Pakistan. Agricultural Statistic of Pakistan, Government of Punjab, Pakistan.

Fladae, O.S., Sowunmi, O.R., Oladipo, A., Tobosun, A., Adewusi, S.R.A. 2003. The level of organic acids in some Nigerian fruit and their effect on mineral availability in composite diet. Pakistan Journal of Nutrition, 2: 82-83.

FAO, 2011. FAOSTAT Online Database, Available at Link http://faostat.fao.org/. Accessed on December 2011.

Gillani, S.S.N. 2002. Development of mango squash from four different cultivars of mango. M.Sc. Thesis. Department of Food Science and Technology, NWFP Agricultural University, Peshawar, Pakistan.

Gorinstein, S., Cvikrova, M., Machackova, I., Haruenkit, R., Park, Y.S., Jung, S.T., Yamamoto, K., Ayala, A.L.M., Katrich, E., Trakhtenberg, S. 2004. Characterization of antioxidant compounds in Jaffa sweeties and white grapefruits. Food Chemistry, 84: $503-510$

Gowda, I.N., Huddar, A.G. 2001. Studies on ripening changes in mango fruit. Journal of Food Science and Technology, 38: 135-137.

Hanaa, Z., Abbasi, A.E. 2012. Potential use of olive mill wastewater in the preparation of functional beverages. International Journal of Food and Beverage Manufacturing, 4: 53-65.

Hanger, L., Lotz, A., Lepeniotis, S. 1996. Descriptive profiles of selected high intensity sweeteners (HIS), HIS blends, and sucrose. Journal of Food Sciences, 61: 456-459.
Hassouna, V. 2010. Impact of olive oil in ready to serve beverages. International Journal of Food and Beverage Manufacturing, 3: 50-60.

Imran, A., Rafiullah, K., Ayube, M. 2000. Effect of added sugar at various concentrations on the storage stability of Guava pulp. Sarhad Journal of Agricultural, 7: 35-39.

Jain, S.K., Khurdiya, D.S. 2005. Vitamin ' $C$ 'enrichment of fruit juice based ready-to-serve beverages through blending of Indian gooseberry juice. Journal of Plant Foods for Human Nutrition, 59: 63-67.

Kalra, S.K., Tandon, D.K. 1984. Guava nectars from sulphited pulp and their blends with mango nectar. Indian Food Packer, 38: 74-77.

Kalra, S.K., Tandon, D.K., Singh, B.P. 1991. Evaluation of mango-papaya blended beverage. Indian Food Packer, 45: 33-35.

Kemal, U., Cevdet, N. 2003. The effect of table olive preparing methods and storage on the composition and nutritive value of olives. Grasasy Aceites, 54: 71-76.

Kinh, Shearer, A.E.H., Dunne, C.P., Hoover, D.G. 2001. Preparation and preservation of apple pulp with chemical preservatives and mild heat. Journal of Food Product, 28: 111-114.

Langthasa, S. 1999. Processing and preservation of apple pulp. Ph.D. Thesis, I.A.R.I. New Delhi, India.

Larmond, E. 1997. Laboratory Methods of Sensory Evaluation of Foods. Publication 1637 Department of Agricultural, Ottawa, Canada.

Lopez. G.I., Pena, P.D., Cid, M.C. 2007. Correlation of selected constituents with the total antioxidant capacity of coffee beverages: influence of the brewing procedure. Journal of Agricultural and Food Chemistry, 55: 6110-6117.

Martin, J.J., Solances, E., Bota, E., Sancho, J. 1995. Chemical and organoleptic changes in pasteurized orange juice. Alimentaria No. 261, 59-63. Food Science and Technology Abstract, 28: 10H139, 1996.

McDonald,S., Prenzler, P.D., Autolovich, M., Robards, K. 2001. Phenolic content and antioxidant activity of olive extracts. Food Chemistry, 73: 73-84.

Mehmood, M.H., Oveisi, M.R., Sadeghi, N., Jannat, B., Hadjibabaie, M., Farahani, E., Akrami, M.R., Namdar, R. 2008. Antioxidant properties of peel and pulp hydro extract in ten Persian pomegranate cultivars. Journal of Biological Sciences, 11: 16001604.

Nchez, M.C., Plaza, L., Adeancos, B., Pilarcano, M. 
2003. Vitamin C, provitamin A, carotenoids and other carotenoids in high-pressurized orange juice during refrigerated storage. Journal of Agricultural and Food Chemistry, 51: 647-653.

Nico, A.I., Rapoport, H.F., Diaz, J., Castillo, R.M.P. 2002. Incidence and population density of plantparasitic nematodes associated with olive planting stocks at nurseries in southern Spain. Plant Disease, 86: $1075-1079$.

Nilugin, S.E., Mahendran, T. 2010. Preparation of readyto-serve (RTS) beverage from palmyrah (borassus flabellifer 1.) fruit pulp. The Journal of Agricultural Sciences, 5: 80-88.

Omar, Haris, S. 2010. Oleuropein in olive and its pharmacological effects. Scientia Pharmaceutica, 78: 2 .

Oszmiañski, J., Wojdylo, A. 2009. Effects of blackcurrant and apple mash blending on the phenolics contents, antioxidant capacity, and colour of juices. Czech Journal of Food Sciences, 5: 338-351.

Otten, J.J., Hellwig, J.P., Meyers, L.D. 2006. Dietary Reference Intakes: The Essential Guide to Nutrient Requirements. Institute of Medicine: The national academic press. Washington, DC., USA.

Perez-Martinez, M.B., Caemmerer, M.P.D., Paz, C., Cid, Kroh, L.W. 2010. Influence of brewing method and acidity regulators on the antioxidant capacity of coffee brews. Journal of Agricultural Food Chemistry, 58: 2958-2965.

Poll, L. 1983. Influence of storage temperature on sensory evaluation and composition of volatiles of Mcintosh apple juice. Lebnsmittel Wissenschaft, Technology, 16: 24-27.

Riaz, R.A., Ali, A., Saleem, M. 1983. Studies on the preparation and storage stability of comminuted kinnow fruit beverage bees. Pakistan Journal of Scientific and Industrial Research, 32: 574-578.

Rodriqo, D., Arranz, J.I., Koch, S., Frigola, A., Rodriqo, M.C., Esteve, M.J., Calvo, C., Radriqo, M. 2003. Physicochemical characteristics and quality of refrigerated Spanish orange carrot juice and influence of storage conditions. Journal of Food Sciences, 68: 2111-2116.

Rosario, M.J.G. 1996. Formulation of ready to drink blends from fruits and vegetables juices. Journal of Phillippines, 9: 201-209.

Saini, S.P.S., Pal, D. 1996. Concentrational behaviour of kinnow juice. Journal of Agricultural Food Chemistry, 55: 890-896.

Sandhu, K.S., Sindhu, J.S. 1992. Studies on the development of multi-fruit ready-to-serve beverages. Journal of Plant Sciences Research, 8: 87-91.

Saxena, A.K., Teotia, M.S., Berry, S.K. 1996. Studies on the development of grape-mango and grapepineapple beverage blends. Indian Food Packaging, 50: 26-29.

Shah, W.H., Sufi, N.A., Zafar, S.I. 1975. Studies on the storage stability of guava fruit juice. Pakistan Journal of Scientific and Industrial Research, 18: 179-183.

Shimoda, M., Osajima, Y. 1981. Studies on off flavor formed during storage of Satsuma mandarin juice. Journal of Agricultural Chemical Society, 55: 319324.

Simmonds, N.W. 1976. Evaluation of Crop Plants. Longman Group Ltd., London. pp. 219-221.

Srividya, N., Ramachandran, P. 2012. Quality evaluation and antioxidant potential of papaya RTS spiced beverage. Journal of Research Sciences, 3: 460.

Steel, R.G.D., Torrie, J.H., Dicky, D.A. 1997. Principles Procedures of Statistics. $3^{\text {rd }}$ edition, McGraw Hill Book Pub. Co. New York, USA.

Tahir, A. 2012. Olive Cultivation in NWFP. http:// thebeautifulpakistan.blogspot.com/2010/03/olivecultivation-in-nwfp.html.

Whitney, E., Rolfes, S. 1999. Understanding Nutrition. Belmont, CA., USA, West/Wadsworth, $8^{\text {th }}$ eds., (W. Rolfes).

Wills, R.B., Lee, T.H., Graham, D., Glasson, W.B., Hall, E.G. 1982. Post Harvest: An Introduction to the Phys. And Handling of Fruits and Vegetables. AVI pub. Co., Westport: 34-35.

Wu, T., Guan, Y., Ye, J. 2007. Determination of flavonoids and ascorbic acid in grapefruit peel and juice by capillary electrophoresis with electrochemical detection. Food Chemistry, 100: 15731579 .

Zeb, A., Ullah, I., Ahmad, A., Ali, K., Ayub, M. 2008. Grapes juice preservation with benzoate and sorbate. Journal of Advances in Food Sciences, 3: 17-21. 